\title{
Proteomic Profiling of Mesenchymal Stem Cell Responses to Mechanical Strain and TGF- $\beta 1$
}

Running Head: Mesenchymal Stem Cell Responses to Mechanical Strain and TGF- $\beta 1$

Kyle Kurpinski ${ }^{1}$, Julia $\mathrm{Chu}^{2}$, Daojing Wang ${ }^{3}$, and Song $\mathrm{Li}^{1,2}{ }^{1,}$

${ }^{1}$ Joint Graduate Program in Bioengineering, UC Berkeley and UC San Francisco, USA;

${ }^{2}$ Department of Bioengineering, University of California, Berkeley;

${ }^{3}$ Life Sciences Division, Lawrence Berkeley National Laboratory, Berkeley, CA 94720.

*Corresponding address:

Song Li, Ph.D.

Department of Bioengineering

University of California, Berkeley

B108A Stanley Hall,

Berkeley, CA 94720-1762

Telephone: (510) 666-2799

Fax: (510) 666-3381

E-mail: song_li@berkeley.edu 


\section{ABSTRACT}

Mesenchymal stem cells (MSCs) are a po tential source of smooth m uscle cells (SMCs) for constructing tissue-engineer ed vascular grafts. However, the details of how specif ic combinations of vascular m icroenvironmental factors regulate MSCs are not well understood. Previous studies have suggested that both m echanical stimulation with uniaxial cyclic strain and chemical stimulation with tr ansforming growth factor $\beta 1$ (TGF- $\beta 1$ ) can induce sm ooth muscle markers in MSCs. In this study, we investigated the combined effects of uniaxial cyclic strain and TGF- $\beta 1$ stim ulation on MSCs. By using a prot eomic analysis, we found differential regulation of several proteins and genes, such as the up-regulation of TGF- $\beta 1$-induced protein igh3 (BGH3) protein levels by TGF- $\beta 1$ and up-regulation of calponin 3 protein level by cyclic strain. At the gene expression level, BGH3 was induced by TGF- $\beta 1$, but calponin 3 was not significantly regulated by mechanical strain or TGF- $\beta 1$, which was in contrast to the synergistic up-regulation of calponin 1 gene expr ession by cyclic strain and TGF- $\beta 1$. Further experim ents with cycloheximide treatment suggested that the up-regulation of calponin 3 by cyclic strain was at post-transcriptional level. Th e results in this study suggest th at both m echanical stimulation and TGF- $\beta 1$ signaling play unique and im portant ro les in the regulation of MSCs at both

transcriptional and post-transc riptional le vels, and that a precise com bination of microenvironmental cues may promote MSC differentiation.

\section{KEY TERMS}

Proteomics, uniaxial cyclic strain, micropatterning, gene expression, differentiation, smooth muscle cells, cell engineering 


\section{INTRODUCTION}

The availability of su itable and abundant ce 11 sources is one of the prim ary lim iting factors in vascular tissue engineering ${ }^{17}$. Human mesenchymal stem cells (MSCs) are expandable, can res ist p latelet adhesion ${ }^{5}$, and have the potentia 1 to dif ferentiate in to sm ooth muscle cells (SMCs) ${ }^{1,7,20}$, which make MSCs a unique cell source fo $r$ the construction of tissue-engineered vascular grafts. Theref ore, it is important to understand how MSCs respond to vascular mechanical and biochemical factors upon implantation or in a bioreactor. W hile previous studies have verified the im portance of $m$ echanical st imulation as a po tential m echanism for driving MSCs toward an SMC phenotype ${ }^{3,4,11,19}$, particularly with regard to the effects of anisotropic mechanical sensing by MSCs ${ }^{11}$, mechanical stimulation alone has not been enough to fully drive MSC differentiation into SMCs. For exam ple, in a previous publication we showed that micropatterned grooves can be used to induce contact guidance in MSCs in order to keep the cells elongated and aligned with the axis of cy clic uniaxial $\mathrm{m}$ echanical strain, which $\mathrm{m}$ ore accurately sim ulates the anisotropic m echanical forces existing with in a blood vessel wall ${ }^{11}$. This anisotropic $\mathrm{m}$ echanical $\mathrm{s}$ timulation alon e was sufficient to upregulate expression of calponin 1 (CNN1), an interm ediate $\mathrm{m}$ arker of SMC diffe rentiation, but was not enough to induce expression of late-stage SMC markers such as Myosin Heavy C hain 11 or Myocardin. It is likely that multiple vascular factors (both mechanical and biochemical) a re involved in the complete MSC to SMC transition.

Transforming growth fa ctor- $\beta 1$ (TGF- $\beta 1$ ) is known to be involved in the regulation of cellular growth, differentiation, migration, and extracellular matrix production ${ }^{2,15,16,24,25}$. It has been shown that TGF- $\quad \beta 1$ can induce either smooth $\mathrm{m} \quad$ uscle (SM) $\mathrm{m}$ arkers or chondrogenic 
differentiation in MSCs, depending on the specif ic culture conditions involved ${ }^{3,8,9,13,25}$. These findings suggest that TGF- $\beta 1$ could play an important role in driving MSCs toward an SMC fate, possibly in combination with other factors. Additionally, TGF- $\beta 1$ has been implicated in several studies inv estigating the respon se of SMCs to $\mathrm{m}$ echanical strain $10,12,18,22$. Here, we hypothesized that a combination of mechanical strain and TGF- $\beta 1$ might induce greater changes in MSCs toward an SMC phenotype.

In this study, m icropatterning techniques were used to control MSC morphology and induce MSC alignment to coinc ide with the axis of uniaxial cyclic $\mathrm{m}$ echanical strain on elas tic poly(dimethyl siloxane) (PDMS) membranes. Our previous studies have shown that MSCs on smooth surfaces have tran sient up-regulatio $\mathrm{n}$ of SMC $\mathrm{m}$ arkers, while $\mathrm{m}$ aintaining MSC alignment in the direction of uniaxial $\mathrm{m}$ echanical strain ind uces sustain ed express ion of SMC markers ${ }^{11,19}$. Additionally, this m echanical stimulation was com bined with TGF- $\beta 1$ chemical stimulation to create a more com plex representation of the microenvironmental factors acting on SMCs in the vasculature.

The results in this stud $\mathrm{y}$ show that $\mathrm{m}$ icropatterned guidance maintains MSC align ment with the axis of stra in either with or without addi $\quad$ tional chem ical stimulation by TGF- $\beta 1$. Subsequent proteom ic analysis re vealed s everal inte resting prot ein changes, such as the upregulation of TGF- $\beta 1$-induced protein ig-h3 (BGH3) with TGF- $\quad \beta 1$ stim ulation and the upregulation of calponin $3(\mathrm{CNN} 3)$ with cyclic $\mathrm{m}$ echanical strain. By further investigating the effects of these factors on MSC gene expression, we found that th e change in BGH3 appears to be controlled at the tra nscriptional level, while the incr ease in CNN3 m ay be controlled posttranscriptionally, in contrast to the synergistic increase of the smooth muscle contractile marker, 
calponin 1 (CNN1), by both cy clic strain and T GF- $\beta 1$. These re sults su ggest both mechanical stimulation and TGF- $\beta 1$ signaling play unique and im portant roles in the regulation of MSCs at both transcriptional and post-transc riptional levels, and that $m$ echanical stimulation can function as a co-factor to promote TGF- $\beta 1$-induced MSC differentiation. 


\section{RESULTS}

MSCs on parallel-oriented microgrooves remained aligned with the axis of strain during both mechanical and chemical stimulation

When MSCs were sub jected to co ncurrent $m$ echanical an d chem ical stim ulation on micropatterned PDMS m embranes, MSCs rem ained aligned with the axis of uniaxial cyclic stretch. Fluorescent staining and confocal microscopy were used to examine the alignment of the F-actin filaments. Figure 1A-B shows that under conditions of uniaxial cyclic strain, stress fibers in MSCs remained well aligned with the directi on of the micropatterned grooves, and hence, the axis of strain. Furthermore, addition of TGF- $\beta 1$ to the culture $\mathrm{m}$ edia did not interfere with this maintenance of alignm ent (Figure 1C-D). These resu lts $v$ erify that th is system is usef $u l f$ or investigating the com bined ef fects of uniaxial cyclic $\mathrm{m}$ echanical strain (on $\mathrm{m}$ icropatterned surface) and TGF- $\beta 1$ stimulation on MSCs.

\section{Mechanical stimulation and TGF- $\beta 1$ caused differential changes in MSC protein expression}

To investigate the overall effects of mechanical strain and TGF- $\beta 1$ stimulation on MSCs, we employed a proteomic analysis of our experimental samples. Figure 2 provides representative 2-D gel images from each of the four experimental groups. In general, protein spots from the 2-D gels displayed excellent separation and f ocusing, and the overall pattern of protein expression appears to be sim ilar for all four groups, sugges ting that $\mathrm{m}$ ost protein levels did not change significantly after 24-hour stimulation. 
Further quantitative analysis of the 2-D gel images revealed differences in several protein spots when com paring between individual sam ples based on a volum e ratio fold-change cutoff value of at least 1.4. Using this criterion, we $\mathrm{f}$ ound 12 protein spots of interest that were then further analyzed with mass spectrometry to identify the proteins (Table 1).

In particular, proteom ic analysis confirm ed at least two protei n changes (eukaryotic translation elongation factor 2/EF2 and BGH3) previously known to be induced by TGF- $\beta 1$, and revealed the changes of severa 1 cytoskeletal proteins $(\mathrm{CNN} 3$, tropom yosin, actin-related protein 3/ARP3 and $\gamma$-actin) induced by mechanical strain, as elaborated upon in the Discussion. For the remainder of the study, we chose to focus on th e following protein cha nges: up-regulation of BGH3 with TGF- $\beta 1$ stimulation, and up-regulation of SM protein CNN3 with cyclic mechanical strain. These two spots of interest are circled on the cyclic strain gel in Figure 2 for reference and are labeled with their respective spot numbers from table 1.

Figure 3 provides close-up images of the protein spots of interest from Figure 2 for easier visual comparison. Spots \#3 and \#6 were analy zed separately with mass spectrometry and both were identified as BGH3 (Figure 3). Gel im ages clearly revealed th at both spots had greater intensity in the sam ples with TGF- $\beta 1$ stim ulation com pared to those without. No obvious differences in these tw o spots were observed between samples with a nd without $\mathrm{m}$ echanical strain. Two adjacent protein spots were both identified as CNN3 by mass spectrometry, and were labeled as spot \#5 (Figure 3). Gel images revealed that the two circled spots had greater intensity with uniaxial cyclic strain than without. No obvious differences in these two spots were observed when comparing conditions of TGF- $\beta 1$ stimulation. 


\section{Mechanical stimulation and TGF- $\beta 1$ caused differential changes in MSC gene expression}

To further investig ate whether the p roteomic changes were regulated at a tran scriptional level in MSCs, we performed quantitative reverse transcription polymerase chain reaction (qRTPCR) analysis to exam ine gene expression of two representative prot eins: BGH3 induced by TGF- $\beta 1$ and CNN3 induced by mechanical strain. As shown in Figure 4, BGH3 gene expression was increased by TGF- $\beta 1$ stimulation but not by mechanical strain, consistent with the change in protein level. However, the gene expression of $\mathrm{CNN} 3$ did not show st atistically signif icant changes in response to either $\mathrm{m}$ echanical or chemical stimulation, demonstrating a difference in transcriptional vs. post-transcriptional regulation of this protein.

Additionally, we exa mined the gene expressi on of another $\mathrm{CNN}$ isofor $\mathrm{m}, \mathrm{CNN} 1$, due to its previously dem onstrated gene- and prot ein-level induction by mechanical strain ${ }^{11}$. A change in CNN1 protein level was not fo und in this proteomic analysis, possibly due to its low relative abundance in the gel, but our results show that both $\mathrm{m}$ echanical strain and TGF- $\beta 1$ alone increased $\mathrm{CNN} 1$ gene expression (F igure 4). Furt hermore, the com bination of the two stim uli had synergistic effects at the gene level; the increase in C NN1 gene e xpression in response to simultaneous exposure to TGF- $\beta 1$ and $\mathrm{m}$ echanical s train was signif icantly gre ater than the CNN1 increase in response to either stimulus alone.

\section{Mechanical regulation of CNN expression was dependent on protein synthesis}

To further investigate how $\mathrm{m}$ echanical $\mathrm{s}$ train regulated CNN3 expr ession at posttranscription level, we treated cel ls with cycloh eximide, an inhi bitor of protein synthesis. As shown in Figure 5, CNN3 protei n expression was induced by mechanical strain, which was 
inhibited by cyclohexim ide, suggesting that $\mathrm{m}$ echanical strain regulates the protein synthesis of CNN3. 


\section{DISCUSSION}

In this study, we si multaneously applied m echanical and ch emical stimulation to MSCs in vitro, $\mathrm{w}$ hile $\mathrm{m}$ aintaining $\mathrm{c}$ ell alignm ent with the a xis of uniaxial cyc lic str ain $\mathrm{v}$ ia micropatterned contact g uidance. Proteomic analysis of the ef fects of combined uniaxial cyc lic strain and TGF- $\beta 1$ stimulation revealed that fewer cha nges were induced on the proteom ic level after only 24 hours of sim ultaneous stimulation, compared to the $>2$-fold changes of over 60 proteins in response to 4-day of TGF- $\beta 1$ stimulation in our previous study ${ }^{25}$. It is ex pected that experiments with longer tim e period would show m ore significant changes. However, the changes in proteins and genes at 24 -hour tim e point have manifested several interesting points, and the changes in protein expression, although less than 2-fold, $\mathrm{m}$ ay contribute to greater overall changes in the a ssembly of actin filaments and cell differentiati on in the long term. For example, mechanical s train up regulated $\mathrm{CNN} 3$ and $\gamma$-actin while downregulating ARP3, whic $\mathrm{h}$ could enhance the assembly of contractile elements but decrease actin branching in the cells. Our previous study with a longer time course (4 days) showed that TGF- $\beta 1$ upregulated $\alpha$-actin while downregulating gelsolin to prom ote actin assembly ${ }^{25}$. Further studies need to be perform ed to monitor te mporal cha nges of the MSC protein profile, which will enable a sy stem biology analysis of interactions and coordination between different signaling pathways (e.g., the increase of CNN3 and $\alpha$-actin and the decrease of ARP3 and ge 1solin) and provide insight in to the underlying mechanisms.

An interesting $\mathrm{f}$ inding in this stud $\mathrm{y}$ is that $\mathrm{c}$ yclic uniaxial stra in (b ut not TGF- $\beta 1$ ) upregulated the level of CNN3 protein in MSCs, but this expression $\mathrm{w}$ as not regulated at the

gene expression level, suggestin $\mathrm{g}$ that other $\mathrm{m}$ echanisms at a post-transcriptional level $\mathrm{m}$ ay 
account for the changes CNN3 protein. In $\mathrm{c}$ ontrast, both mechanical strain and TGF- $\beta 1$ induced an increase in CNN1 gene expre ssion, and the com bination of the two factors further induced a synergistic increase in CNN1 gene expression. These results suggest that m echanical strain and TGF- $\beta 1$ may regulate the expression of CNN1 a nd CNN3 through different $\mathrm{m}$ echanisms, and that the co mbination of mechanical strain and TGF- $\beta 1$ can prom ote MSC differentiation into SMCs more effectively than either stimulus alone. It is noted that CNN1 (basic isoform) is only expressed in the SMC lineage while CNN3 (acidic isoform) is expressed in both smooth $\mathrm{m}$ uscle and other non-m uscle tissues ${ }^{14}$. This indicates that the signaling pathways involved in the transcriptional activa tion of these two calpon in isoform $\mathrm{s}$ are quite different. Although the transcriptional factors involved in $\mathrm{CNN} 1$ and $\mathrm{CNN} 3$ have not $\mathrm{b}$ een clearly iden tified, our data suggests that the prom oter of CNN1, but not $\mathrm{CNN} 3$, has the binding sites regulated by TGF- $\beta 1$ mediated signaling, e.g., Sm ads and/or extracellu lar-regulated kinases, which awaits $\mathrm{m}$ ore indepth investigations.

It was previously show $\mathrm{n}$ that BGH3 expression is inducible by TGF- $\beta 1^{6,21}$, a nd may play an inh ibitory ro le in osteoblast differentiation ${ }^{23}$. P roteomic analysis from this study confirmed the up-regulation of BGH3 in MSCs via TGF- $\beta 1$ stimulation, and BGH3 induction is also regulated at the tra nscriptional level. Howe ver, cyc lic uniaxial strain appeared to have no additional effect on BGH3 expression at either th e gene or protein leve 1. Interestingly, BGH3 appeared as two spots of varying m olecular weight on the 2-D gels, suggesting the presence of a potential degradation product of BGH3 at the lower m olecular weight. Since an increase in BGH3 could potentially lead to a $\mathrm{d}$ ecrease in bone-related gene expression ${ }^{23}$, this suggests that 
our culture conditions $\mathrm{m}$ ay help to guide MS C differentiation away from an osteogenic phenotype.

TGF- $\beta 1$ appears to be an i mportant che mical factor for driving MSCs toward an SMC phenotype as previously hypothesized ${ }^{25}$. Long-term treatment of MSCs with TGF- $\beta 1$ induces the expression of m yocardin, a master transcriptional factor in SMCs (unpublished observation). However, the addition of m echanical s train to the culture conditions ha s additional effects on intermediate contractile markers, suggesting that mechanical strain can function as a co-factor i n driving MSCs toward a contractile SMC phenotype.

Lastly, since we have previ ously shown that cell orientat ion affects cell responses to uniaxial s train ${ }^{11}$, we cannot exclude the possi bility that other $\mathrm{m}$ odes/directions of $\mathrm{m}$ echanical strain could also work together with TGF- $\beta 1$ to regulate MSC functions. In general, the results of this study demonstrated that MSC response to grow th factor exposure and m echanical strain can be a com plex function of $m$ ultiple stim uli, an $d$ the $r$ esults warran $t$ f urther inves tigation with regard to various combinations of chemical and mechanical regulators of vascular differentiation. 


\section{MATERIALS AND METHODS}

\section{Microfabrication and Soft Lithography}

To create patterned m embranes with parallel microgrooves $(10 \mu \mathrm{m}$ wide, $3 \mu \mathrm{m}$ deep, 10 $\mu \mathrm{m}$ distance between each groove), we used $\mathrm{m} \quad$ icrofabrication techn iques as described in a previous publication ${ }^{11}$.

\section{Cell Culture and Cyclic Strain}

Human MSCs were acquired from $\mathrm{Ca}$ mbrex Corp and were $\mathrm{m}$ aintained $\mathrm{f}$ or growth without differentiation as previously described ${ }^{11}$. To stim ulate MSCs w ith cyclic strain, MSCs were first seeded on m icropatterned membranes within a cus tom-built uniaxial stretch machine as previously described ${ }^{11}$. "+cyclic strain" samples were subjected to $5 \%$ uniaxial cyclic strain at a frequency of 60 cycles per $\mathrm{m}$ inute (cpm). To acc ount for fluid shear stress effects, "-cyclic strain" samples also moved back and forth at $60 \mathrm{cpm}$, but with no strain on the m embrane. Additionally, TGF- $\beta 1$ was added to the appropriate samples as described in the next section.

\section{TGF- $\beta 1$ Stimulation}

Prior to stimulation with cyclic mechanical strain, MSCs on the micropatterned elastic PDMS membranes were cultured for 24 hours in a medium with Dulbecco's Modif ied Eagle's Medium supplem ented with $10 \%$ fetal bovine se rum, $1 \%$ penicillin-streptom ycin and $1 \%$

fungizone (all from Invitrogen Corp.) in the absence or presence of TGF- $\quad \beta 1(5 \mathrm{ng} / \mathrm{m} \mathrm{L})$ (PeproTech, Rocky Hill, NJ). Then the sam ples were kept a s un-stretched controls or subjected to cyclic s train for ad ditional 24 hours. The e xperimental setup resu lted in a to tal of four 
different experimental groups: (1) -strain, -TGF- $\beta 1$, (2) +strain, -TGF- $\beta 1$, (3) -strain, +TGF- $\beta 1$, or (4) +strain, +TGF- $\beta 1$.

\section{Immunofluorescent Staining and Confocal Microscopy}

Immunostaining and confocal $\mathrm{m}$ icroscopy were used to visualize the structure of the cytoskeleton in MSCs. MSCs were fixed with $4 \%$ paraform aldehyde, permeabilized with $0.5 \%$ Triton X-100, and stained for actin filaments by using rhodamine-conjugated phalloidin.

A Leica TCL SL confocal microscopy system, including He/Ne laser sources and a Leica DM IRB microscop e, was used to cap ture multiple $\mathrm{Z}$-section im ages $(\sim 0.4 \mu \mathrm{m}$ thick sections over a range of $\sim 6 \mu \mathrm{m}$ ) for a given specimen. These sectio ns were subsequently projected to a single plane to create an overall im age of the specim en. All im ages in a given group were collected with the same hardware and software settings.

\section{Two-Dimensional Differential In-Gel Electrophoresis (2D-DIGE) and Immunoblotting}

\section{Analysis}

Cells were lysed with $100 \mu \mathrm{L}$ lysis buffer (containing $25 \mathrm{mM}$ Tris, $\mathrm{pH} 7.4,0.5 \mathrm{M} \mathrm{NaCl}$, $1 \%$ Triton X-100, 0.1\% SDS, $1 \mathrm{~m} \quad$ M PMSF, $10 \mu \mathrm{g} / \mathrm{mL} 1$ eupeptin, and $1 \mathrm{~m} \quad \mathrm{M} \mathrm{Na}_{3} \mathrm{VO}_{4}$ ) per membrane. Protein lysates were centrifuged to pellet cellu lar d ebris, and the sup ernatant was removed and quantified using DC Protein Assay (Bio-Rad Inc.).

Protein sam ples were processed in urea buf fer and subjected to 2D-DIGE analysis (Applied Biomics, Inc, Hayward, CA). Briefly, samples of equal loading were labeled with Cy2, Cy3, or Cy5 dyes (GE Healthcare/Am ersham, Piscataway, NJ) on ice $\mathrm{f}$ or 30 m inutes. Labeled 
samples were mixed with a rehydration buffer and then subjected to isoelectric focusing (IEF) on a 13-cm precast IPG (immobilized $\mathrm{pH}$ gradient) strip (pH 3-10, GE Healthcare/Amersham) using an Amersham Pharmacia IPGPHOR unit with a power supply (EPS 3501XL) in gradient $m$ ode. The sam ples were then separated in the second dim ension by sodium dodecyl sulfate polyacrylamide gel electrophoresis (SDS-PAGE). Subsequent 2- D gels were scanned using Typhoon Trio scanner (GE Healthcare/Am ersham), and im ages were analyzed using ImageQuant and DeCyder software (GE Heal thcare/Amersham). Individual fluorescent dye signals were converted to black and white im ages corresponding to the individual samples, and gel images are presented in Figure 2.

To obtain a com prehensive analysis of the various protein spot com parisons between each of the four groups, samples were run in one of the following sets of gels, with three samples in each set: (1) -strain /-TGF, +strain/-TGF, a nd +strain/+T GF (2) -strain/-TGF, -strain /+TGF, +strain/+TGF. Quantitative com parisons were th en made between two individual sam ples for each of the three pos sible com binations in the two s eparate gels (to tal of 6 crosswis e comparisons between s amples). In each gel, the indiv idual volum e ratios (sam ples 1 vs. 2 , samples 1 vs. 3, and samples 2 vs. 3) were calcul ated for each pro tein spot and used determ ine relative protein expression. To sim plify the pres ented data, only com parisons to the negative control sample (i.e., “-strain/-TGF”) are presented.

Immunoblotting analysis was perform ed as describ ed previously ${ }^{11}$. The antib odies against CNN3 and actin were obtained from Santa Cruz Biotechnologies, Inc. 


\section{Protein Spot Identification with Mass Spectrometry}

To determ ine the iden tities of the $\mathrm{d}$ ifferentially-regulated pr oteins within the 2-D gel spots, the gels were subjected to in-gel tryptic digestion and peptide extraction, followed by mass spectrometry analysis as descri bed in a previo us publication ${ }^{25}$. Brief ly, the protein spots of interest were first manually rem oved from the ge ls using a razor blade and then digested with $\operatorname{trypsin}^{25}$. The digested protein samples were then subjected to Q-TOF mass spectrometry using a hybrid quadrupole/orthogonal time-of-flight mass spectrom eter, Q-TOF API US ( Waters), interfaced with a capillary liquid chromatography system (Waters), which constitutes a complete liquid chrom atography-tandem $\mathrm{m}$ ass spec trometry (LC-MS/MS) analysis ${ }^{25}$. MS /MS spectra were obtained in a data-dependent acquisition mode, and mass spectra w ere processed by using MassLynx 4.0 software ${ }^{25}$. Protein identities were determ ined using the Protein Global Server 1.0/2.0 software, and were further confirm ed by Mascot (www.matrixscience.com) by using the MS/MS peak lists exported from MassLynx ${ }^{25}$.

\section{RNA Isolation and qRT-PCR}

Cells were lysed with $1.0 \mathrm{~m}$ L of RNA STAT-60 reagent (Tel-Tes t Inc.) per m embrane. RNA was extracted using chloroform and phenol extractions, precipitated using isopropanol, and the resulting RNA pellet was washed with $75 \%$ ethanol. RNA pellets were resuspended in $20 \mu \mathrm{L}$ DEPC-treated $\mathrm{H}_{2} \mathrm{O}$ and were quantified as described. cDNA was synt hesized using two-step reverse-transcription with the ThermoScript RT-PCR system (Invitrogen), followed by qRT-PCR with SYBR-green reag ent and the ABI Prism $\quad$ 7000 Sequence Detection System (Applied Biosystems). Prim ers for the g enes of interes $t$ were all designed using the ABI Prism Primer 
Express software v.2.0 (Applied Biosystems). Refer to Table 2 for a full list of primer sequences. The gene levels from each sample were norm alized to $18 \mathrm{~S}$ levels from the sam e sample. Data was analyzed using ABI Prism 7000 SDS software (Applied Biosystems).

\section{Statistical analysis}

PCR data was analyzed for statistical si gnificance between all groups using ANOVA followed by a Holm's t-test for comparisons between each individual group. ${ }^{*} \mathrm{P}<0.05$ using onetail t-test $(\mathrm{n}=5)$. Data is presented as mean \pm standard deviation. All replicates were obtained from independent experiments. 


\section{ACKNOWLEDGEMENTS}

We thank Drs. Jerry Shen and Jian Liao at Applied Biomics Inc. for their help in 2D-DIGE analysis. This work was supported in part by grants HL079419, HL078534 and HL083900 from NIH. Work also funded by the U.S. Department of Energy under Contract No. DE-AC02-05CH11231. 


\section{REFERENCES}

1. Caplan, A.I. and S.P. Bruder, Mesenchymal stem cells: building blocks for molecular medicine in the 21st century. Trends Mol Med, 7(6): p. 259-64.2001.

2. Derynck, R. and Y.E. Zhang, Smad-dependent and Smad-independent pathways in TGFbeta family signalling. Nature, 425(6958): p. 577-84.2003.

3. Gong, Z. and L.E. Niklason, Small-diameter human vessel wall engineered from bone marrow-derived mesenchymal stem cells (hMSCs). Faseb J, 22(6): p. 1635-48.2008.

4. Hamilton, D.W., T.M. Maul, and D.A. Vorp, Characterization of the response of bone marrow-derived progenitor cells to cyclic strain: implications for vascular tissueengineering applications. Tissue Eng, 10(3-4): p. 361-9.2004.

5. Hashi, C.K., et al., Antithrombogenic property of bone marrow mesenchymal stem cells in nanofibrous vascular grafts. Proc Natl Acad Sci U S A.2007.

6. Irigoyen, M., et al., TGFbeta-induced protein mediates lymphatic endothelial cell adhesion to the extracellular matrix under low oxygen conditions. Cell Mol Life Sci, 65(14): p. 2244-55.2008.

7. Jiang, Y., et al., Pluripotency of mesenchymal stem cells derived from adult marrow. Nature, 418(6893): p. 41-9.2002.

8. Johnstone, B., et al., In vitro chondrogenesis of bone marrow-derived mesenchymal progenitor cells. Exp Cell Res, 238(1): p. 265-72.1998.

9. Kinner, B., J.M. Zaleskas, and M. Spector, Regulation of smooth muscle actin expression and contraction in adult human mesenchymal stem cells. Exp Cell Res, 278(1): p. 7283.2002. 
10. Kulik, T.J. and S.P. Alvarado, Effect of stretch on growth and collagen synthesis in cultured rat and lamb pulmonary arterial smooth muscle cells. J Cell Physiol, 157(3): p. 615-24.1993.

11. Kurpinski, K., et al., Anisotropic mechanosensing by mesenchymal stem cells. Proc Natl Acad Sci U S A, 103(44): p. 16095-100.2006.

12. Li, Q., et al., Stretch-induced collagen synthesis in cultured smooth muscle cells from rabbit aortic media and a possible involvement of angiotensin II and transforming growth factor-beta. J Vasc Res, 35(2): p. 93-103.1998.

13. Mackay, A.M., et al., Chondrogenic differentiation of cultured human mesenchymal stem cells from marrow. Tissue Eng, 4(4): p. 415-28.1998.

14. Maguchi, M., et al., Molecular cloning and gene mapping of human basic and acidic calponins. Biochemical and Biophysical Research Communications, 217(1): p. 23844.1995.

15. Massague, J. and D. Wotton, Transcriptional control by the TGF-beta/Smad signaling system. Embo J, 19(8): p. 1745-54.2000.

16. Moustakas, A., S. Souchelnytskyi, and C.H. Heldin, Smad regulation in TGF-beta signal transduction. J Cell Sci, 114(Pt 24): p. 4359-69.2001.

17. Nerem, R.M. and D. Seliktar, Vascular tissue engineering. Annu Rev Biomed Eng, 3: p. 225-43.2001.

18. O'Callaghan, C.J. and B. Williams, Mechanical strain-induced extracellular matrix production by human vascular smooth muscle cells: role of TGF-beta(1). Hypertension, 36(3): p. 319-24.2000. 
19. Park, J.S., et al., Differential effects of equiaxial and uniaxial strain on mesenchymal stem cells. Biotechnol Bioeng, 88(3): p. 359-68.2004.

20. Pittenger, M.F., et al., Multilineage potential of adult human mesenchymal stem cells. Science, 284(5411): p. 143-7.1999.

21. Skonier, J., et al., beta ig-h3: a transforming growth factor-beta-responsive gene encoding a secreted protein that inhibits cell attachment in vitro and suppresses the growth of $\mathrm{CHO}$ cells in nude mice. DNA Cell Biol, 13(6): p. 571-84.1994.

22. Sumpio, B.E., et al., Enhanced collagen production by smooth muscle cells during repetitive mechanical stretching. Arch Surg, 123(10): p. 1233-6.1988.

23. Thapa, N., K.B. Kang, and I.S. Kim, Beta ig-h3 mediates osteoblast adhesion and inhibits differentiation. Bone, 36(2): p. 232-42.2005.

24. Topper, J.N., TGF-beta in the cardiovascular system: molecular mechanisms of a context-specific growth factor. Trends Cardiovasc Med, 10(3): p. 132-7.2000.

25. Wang, D., et al., Proteomic profiling of bone marrow mesenchymal stem cells upon transforming growth factor beta1 stimulation. J Biol Chem, 279(42): p. 43725-34.2004. 


\section{TABLES}

Table 1. Proteins identified by proteomic analysis

\begin{tabular}{|c|c|c|c|c|c|c|c|}
\hline $\begin{array}{l}\text { Protein } \\
\text { symbol }\end{array}$ & Protein Name & $\begin{array}{l}\text { MW } \\
\text { (kD) }\end{array}$ & PI & $\begin{array}{c}\text { Spot } \\
\text { Number }\end{array}$ & $\begin{array}{c}\text { [-strain/+TGF]/ [- } \\
\text { strain/-TGF] } \\
\text { Ratio } \\
\end{array}$ & $\begin{array}{c}\text { [+strain/-TGF]/ [- } \\
\text { strain/-TGF] } \\
\text { Ratio } \\
\end{array}$ & $\begin{array}{c}\text { [+strain/+TGF] } \\
\text { [-strain/-TGF] } \\
\text { Ratio } \\
\end{array}$ \\
\hline EF2 & $\begin{array}{l}\text { Eukaryotic Translation } \\
\text { Elongation Factor } 2\end{array}$ & 96.2 & 6.4 & 1 & 1.26 & 1.97 & 1.87 \\
\hline FINC & $\begin{array}{l}\text { C-terminus truncated, } \\
\text { Fibronectin } 1\end{array}$ & 243.0 & 5.6 & 2 & 1.47 & 1.11 & 1.54 \\
\hline BGH3 & $\begin{array}{c}\text { Transforming growth } \\
\text { factor-beta-induced protein } \\
\text { ig-h3 [Precursor] }\end{array}$ & 75.2 & 7.6 & 3 & 1.08 & 1.72 & 1.77 \\
\hline SERC & $\begin{array}{c}\text { Phosphoserine } \\
\text { aminotransferase isoform 1 }\end{array}$ & 40.8 & 7.6 & 4 & -1.40 & 1.19 & 1.12 \\
\hline $\mathrm{CNN} 3$ & Calponin 3 & 36.6 & 5.7 & 5 & 1.62 & 1.00 & 1.65 \\
\hline BGH3 & $\begin{array}{c}\text { N-terminus truncated, } \\
\text { Transforming growth } \\
\text { factor-beta-induced protein } \\
\text { ig-h3 [Precursor] }\end{array}$ & 75.2 & 7.6 & 6 & 1.05 & 1.61 & 1.58 \\
\hline CALR & Calreticulin & 48.3 & 4.3 & 7 & -1.56 & -1.10 & -1.45 \\
\hline $\mathrm{AK} 1 \mathrm{C} 1$ & $\begin{array}{l}\text { Aldo-keto reductase family } \\
1\end{array}$ & 37.2 & 7.1 & 8 & -1.01 & -1.23 & -1.55 \\
\hline TPM1 & Tropomyosin 1 alpha chain & 32.8 & 4.7 & 9 & -1.43 & -1.12 & -1.41 \\
\hline ARP3 & $\begin{array}{c}\text { ARP3 actin-related protein } \\
3 \text { homolog }\end{array}$ & 47.8 & 5.6 & 10 & -1.72 & -1.24 & -1.58 \\
\hline NQO1 & $\begin{array}{l}\text { NAD(P)H menadione } \\
\text { oxidoreductase } 1\end{array}$ & 30.9 & 8.9 & 11 & 1.02 & -1.07 & -1.45 \\
\hline ACTG & $\begin{array}{l}\text { C-terminus half of full } \\
\text { length gamma actin }\end{array}$ & 18.7 & 5.2 & 12 & 1.64 & -1.28 & 1.37 \\
\hline
\end{tabular}


Table 2. Primer sequences used for qRT-PCR

\begin{tabular}{|c|c|c|}
\hline Gene name & Forward Primer (5' to 3') & Reverse primer (5' to 3') \\
\hline BGH3 & AATCTGTGGCAAATCAACAGTCA & TCATATCCAGGACAGCACTCGTA \\
\hline CNN1 & GCATGTCCTCTGCTCACTTCAA & GGGCCAGCTTGTTCTTAACCT \\
\hline CNN3 & GGCTCTAGCAGGTCTGGCTAAA & AATGTCAATGGTTGTATGGAATCCT \\
\hline
\end{tabular}




\section{FIGURE LEGENDS}

Figure 1. Immunofluorescent staining of F-actin cytosk eletal fila ments in MSCs. Cells we re cultured in the absence or presen ce of TGF- $\beta 1(5 \mathrm{ng} / \mathrm{m} \mathrm{L})$ for 24 hours u nder static conditions, followed by addition al 24-hours s tatic culture or m echanical stimulation (strain is in left-righ $\mathrm{t}$ direction). Scale bar is $100 \mu \mathrm{m}$.

Figure 2. Representative 2-D gel images of protein samples taken from MSCs after chemical (5 $\mathrm{ng} / \mathrm{mL} \mathrm{TGF}-\beta 1)$ and/or m echanical stimulation. Original fluorescent signals were converted to black and white im ages shown here. Spots of particular interest are circled and num bered according to Table 1. Spots 3 and 6 are BGH3. Spot 5 is CNN3.

Figure 3. Comparison of BGH3 and CNN3 spot intensities taken from 2-D gel analysis of MSCs after chemical (5 ng/mL TGF- $\beta 1$ ) and/or mechanical stimulation. All circled spots correspond to spot numbers from Table 1.

Figure 4. Changes in MSC gene expression induced by chemical ( $5 \mathrm{ng} / \mathrm{mL}$ TGF- $\beta 1)$ and/or mechanical stimulation. Data represents relative mRNA expression levels normalized to 18S. $* \mathrm{P}<0.05$ using one-tail $\mathrm{t}$-test $(\mathrm{n}=5)$.

Figure 5. Post-transcriptional regulation of CNN3. Cells were cultured for 1 day, and either subjected to mechanical stimulation or kept as static control in the absence or presence of cycloheximide $(10 \mu \mathrm{g} / \mathrm{mL})$ for 24 hours. Protein lysates from each sample were subjected to immunoblotting analysis by using an antibody against CNN3 or actin (to show equal loading of proteins). 
Figure 1

- cyclic strain

+ cyclic strain
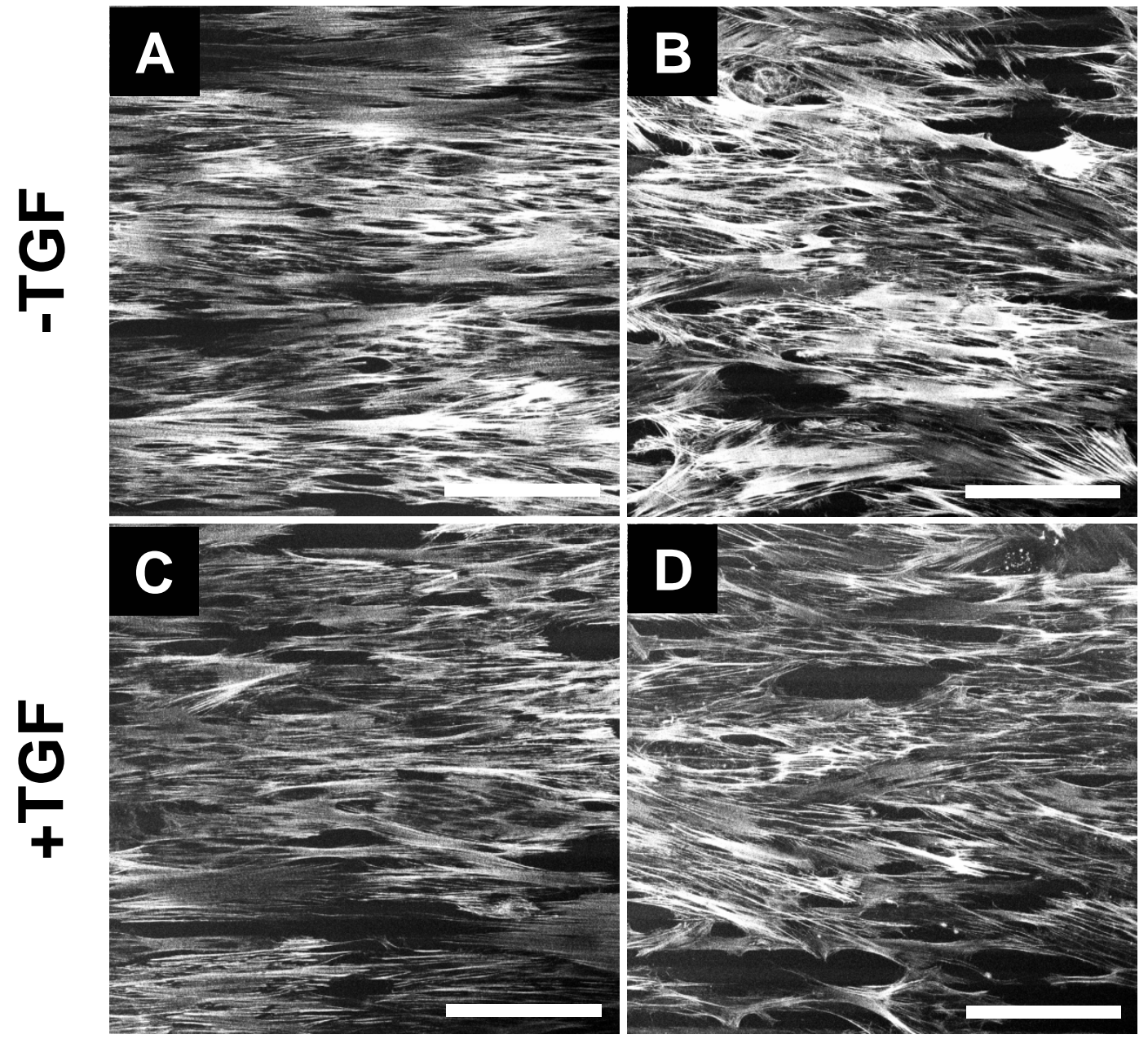
Figure 2

- cyclic strain
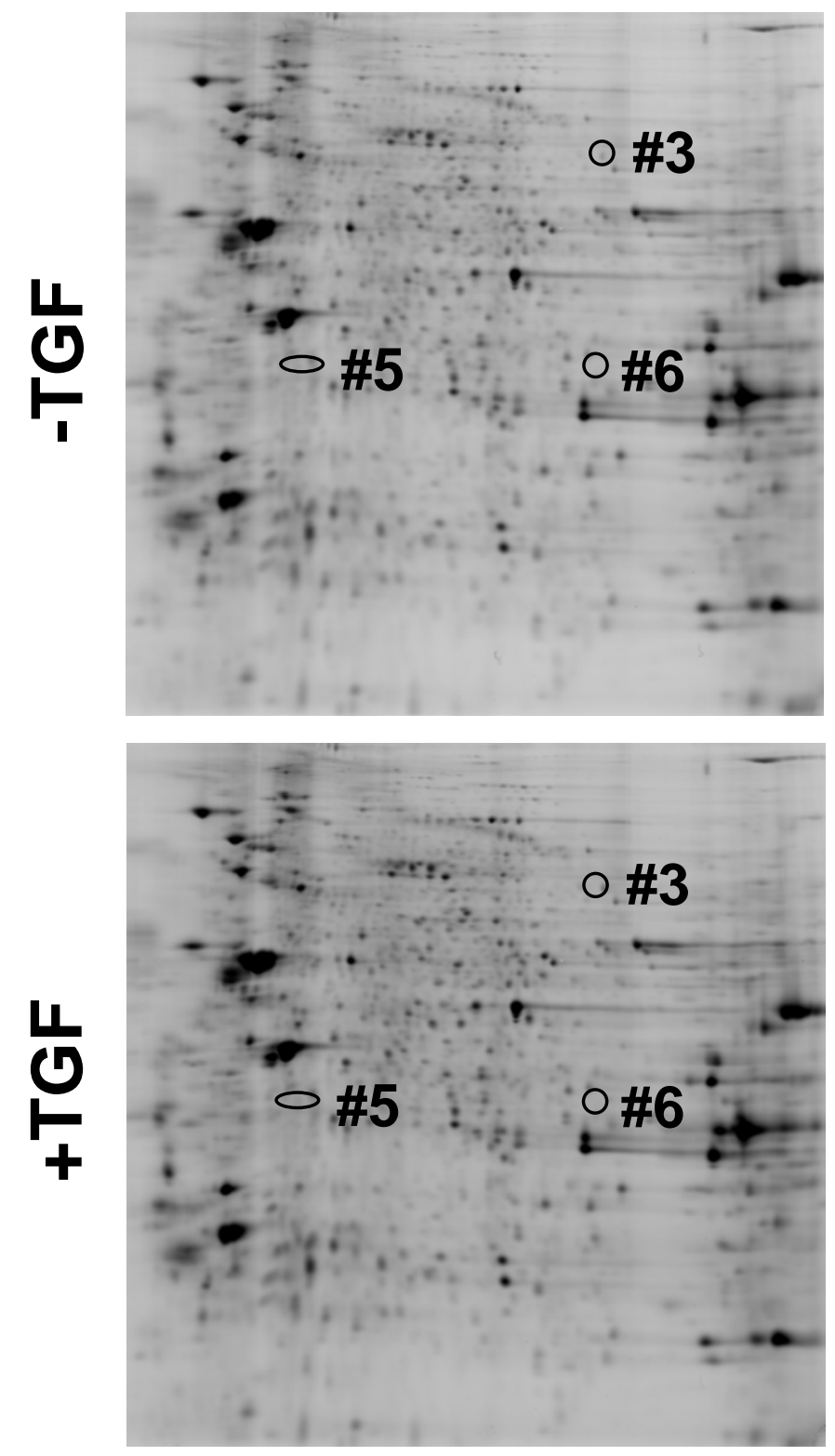

+ cyclic strain
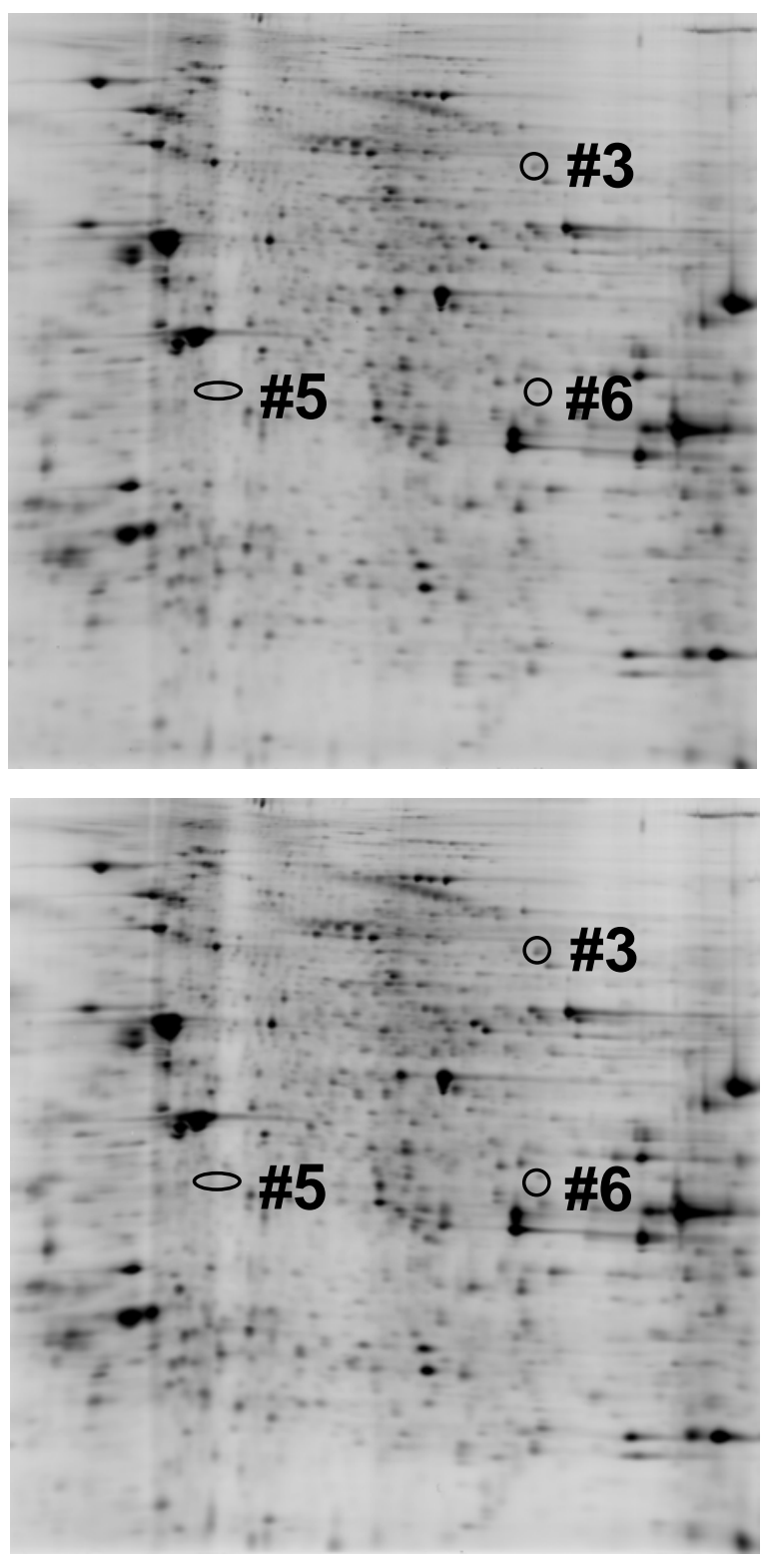
Figure 3

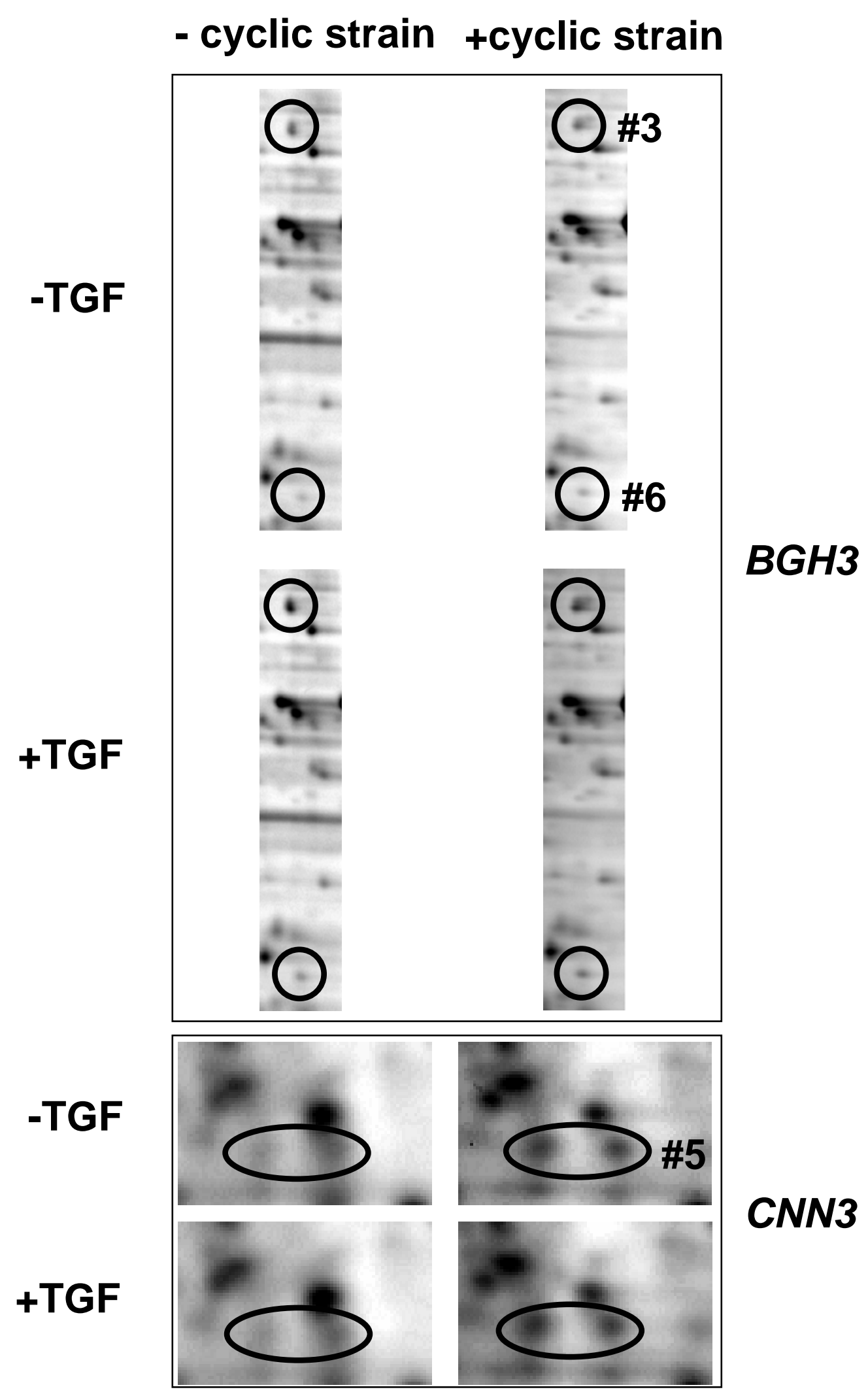



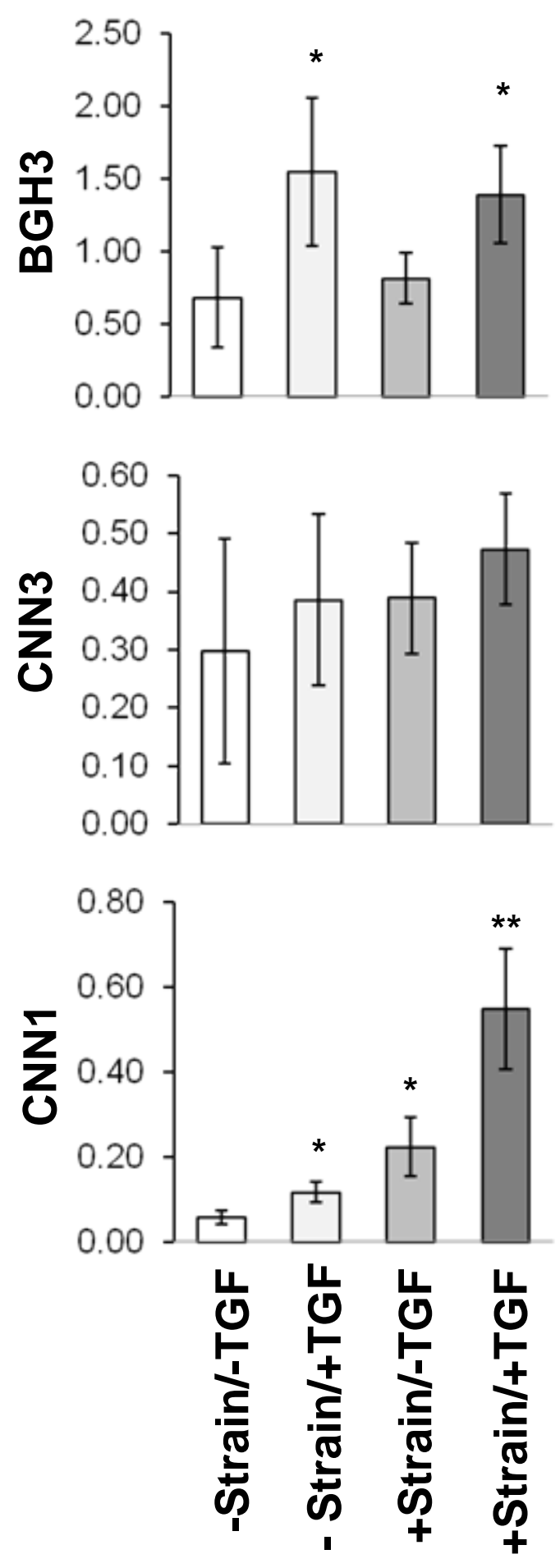


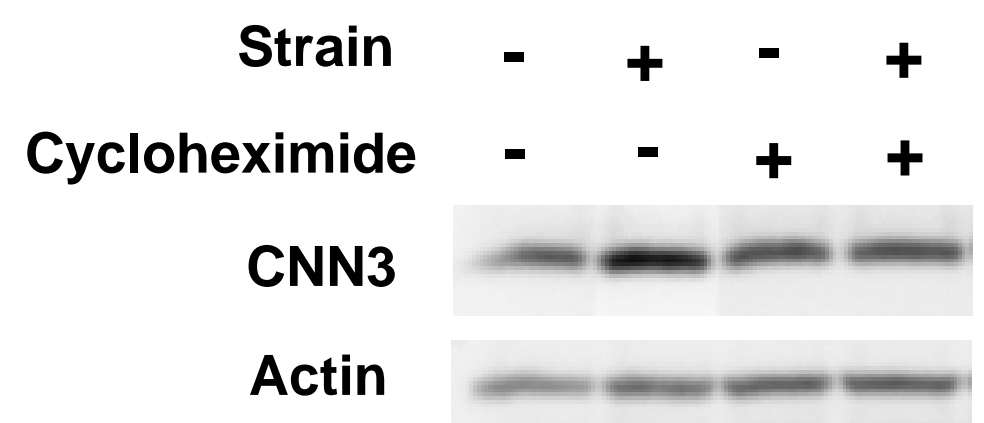


Table 1. Proteins identified by proteomic analysis

\begin{tabular}{|c|c|c|c|c|c|c|c|}
\hline $\begin{array}{l}\text { Protein } \\
\text { symbol }\end{array}$ & Protein Name & $\begin{array}{l}\text { MW } \\
\text { (kD) }\end{array}$ & PI & $\begin{array}{l}\text { Spot } \\
\text { No. }\end{array}$ & $\begin{array}{c}\text { [-strain/+TGF] } / \\
\text { [-strain/-TGF] } \\
\text { Ratio }\end{array}$ & $\begin{array}{c}\text { [+strain/-TGF] }] \\
\text { [-strain/-TGF] } \\
\text { Ratio }\end{array}$ & $\begin{array}{c}\text { [+strain/+TGF] }] \\
\text { [-strainl-TGF }] \\
\text { Ratio }\end{array}$ \\
\hline EF2 & $\begin{array}{l}\text { Eukaryotic Translation } \\
\text { Elongation Factor } 2\end{array}$ & 96.2 & 6.4 & 1 & 1.97 & 1.26 & 1.87 \\
\hline FINC & $\begin{array}{l}\text { C-terminus truncated, } \\
\text { Fibronectin } 1\end{array}$ & 243 & 5.6 & 2 & 1.11 & 1.47 & 1.54 \\
\hline BGH3 & $\begin{array}{l}\text { Transforming growth factor- } \\
\text { beta-induced protein ig-h3 } \\
\text { [Precursor] }\end{array}$ & 75.2 & 7.6 & 3 & 1.72 & 1.08 & 1.77 \\
\hline SERC & $\begin{array}{c}\text { Phosphoserine } \\
\text { aminotransferase isoform } 1\end{array}$ & 40.8 & 7.6 & 4 & 1.19 & -1.40 & 1.12 \\
\hline CNN3 & Calponin 3 & 36.6 & 5.7 & 5 & 1.00 & 1.62 & 1.65 \\
\hline BGH3 & $\begin{array}{l}\text { N-terminus truncated, } \\
\text { Transforming growth } \\
\text { factor-beta-induced protein } \\
\text { ig-h3 [Precursor] }\end{array}$ & 75.2 & 7.6 & 6 & 1.61 & 1.05 & 1.58 \\
\hline CALR & Calreticulin & 48.3 & 4.3 & 7 & -1.10 & -1.56 & -1.45 \\
\hline AK1C1 & Aldo-keto reductase family 1 & 37.2 & 7.1 & 8 & -1.23 & -1.01 & -1.55 \\
\hline TPM1 & Tropomyosin 1 alpha chain & 32.8 & 4.7 & 9 & -1.12 & -1.43 & -1.41 \\
\hline ARP3 & $\begin{array}{c}\text { ARP3 actin-related protein } 3 \\
\text { homolog }\end{array}$ & 47.8 & 5.6 & 10 & -1.24 & -1.72 & -1.58 \\
\hline NQO1 & $\begin{array}{l}\mathrm{NAD}(\mathrm{P}) \mathrm{H} \text { menadione } \\
\text { oxidoreductase } 1\end{array}$ & 30.9 & 8.9 & 11 & -1.07 & 1.02 & -1.45 \\
\hline ACTG & $\begin{array}{l}\text { C-terminus half of full length } \\
\text { gamma actin }\end{array}$ & 18.7 & 5.2 & 12 & -1.28 & 1.64 & 1.37 \\
\hline
\end{tabular}


Table 2. Primers for RT-PCR

\begin{tabular}{|c|c|c|}
\hline Gene name & Forward Primer (5' to $\mathbf{3}^{\prime}$ ) & Reverse primer (5' to $\mathbf{3}^{\prime}$ ) \\
\hline BGH3 & AATCTGTGGCAAATCAACAGTCA & TCATATCCAGGACAGCACTCGTA \\
\hline CNN1 & GCATGTCCTCTGCTCACTTCAA & GGGCCAGCTTGTTCTTAACCT \\
\hline CNN3 & GGCTCTAGCAGGTCTGGCTAAA & AATGTCAATGGTTGTATGGAATCCT \\
\hline
\end{tabular}

